\title{
REGULASI DAN EKSISTENSI KOPERASI SYARIAH DI KOTA DEPOK
}

\author{
Hasnil Hasyim \\ Dosen Tetap Perbankan Syariah STAI Al Hidayah \\ Email: hasnil.alhidayah@gmail.com
}

\begin{abstract}
Syariah cooperation marked as a trend among people nowadays. Unfortunately, regulation for syariah cooperation still referred to UU No. 25/ 1992 which excluded syariah cooperation. This research tried to answer some questions: (1) How is the adjustment between cooperation principles and syariah economy cooperation? (2) What is the foundation of law being employed in the operationalization of syariah cooperation in Depok? (3) How is the existence of syariah cooperation in Bandung nowadays? Research results have revealed the ethic and philosophy of cooperative movement has many adjustments with Islamic teachings concerning the importance of cooperation and helping each other (ta'awun), brotherhood (ukhuwah), and democracy (musyawarah). Basic of law for syariah cooperation is actually referring on Pancasila as ideal foundation, Constitution of UUD '45 as structural foundation, and Letters of Minister of Cooperative and Small Medium Business as operational foundation. Majority of syariah cooperation in Depok has not yet acquired a legal entity for cooperative, due to fact that their statutes also has not yet legalized by the Minister of Cooperative and Small Medium Business. Beside that,main goal of syariah cooperation for economic and community development and the end result on improvement economic their member, which suitable based on islamic religion.
\end{abstract}

Keywords: regulations, cooperatives, Sharia, Sharia cooperatives.

\begin{abstract}
ABSTRAK
Kerjasama Syariah ditandai sebagai tren di antara orang-orang saat ini. Sayangnya, regulasi untuk kerja sama syariah masih mengacu pada UU No. 25/1992 yang mengecualikan kerja sama syariah. Penelitian ini mencoba menjawab beberapa pertanyaan: (1) Bagaimana penyesuaian prinsip kerja sama dan kerja sama ekonomi syariah? (2) Apa landasan hukum yang digunakan dalam operasionalisasi kerja sama syariah di Depok? (3) Bagaimana keberadaan kerja sama syariah di Bandung saat ini? Hasil penelitian telah mengungkapkan etika dan filosofi gerakan koperasi memiliki banyak penyesuaian dengan ajaran Islam mengenai pentingnya kerjasama dan saling membantu (ta'awun), persaudaraan (ukhuwah), dan demokrasi (musyawarah). Dasar hukum untuk kerja sama syariah sebenarnya merujuk pada Pancasila sebagai landasan ideal, UUD 45 sebagai landasan struktural, dan Surat Menteri Koperasi dan Usaha Kecil Menengah sebagai landasan operasional. Mayoritas kerjasama syariah di Depok belum mengakuisisi badan hukum untuk koperasi, karena undang-undang mereka juga belum disahkan oleh Menteri Koperasi dan Usaha Kecil Menengah. Selain itu, tujuan utama kerja sama syariah untuk pengembangan ekonomi dan masyarakat dan hasil akhir pada peningkatan ekonomi anggotanya, yang sesuai berdasarkan agama Islam.
\end{abstract}

\section{A. PENDAHULUAN}

Pasal 33 Ayat (4) UUD RI Tahun 1945 menyatakan "Perekonomian nasional
diselenggarakan atas dasar demokrasi ekonomi dengan prinsip kebersamaan, efisiensi berkeadilan, berkelanjutan, berwawasan lingkungan, kemandirian, serta dengan menjaga keseimbangan kemajuan 
dan kesatuan ekonomi nasional". Rumusan pasal tersebut memerlihatkan bahwa Indonesia merupakan negara yang akan menciptakan kemakmuran dan keadilan sosial secara berkeseimbangan dan keadilan di segala bidang kehidupan dan penghidupan rakyatnya. Konsekwensinya negara harus memberikan perhatian yang seimbang terhadap peningkatan kemandirian ekonomi dari semua lapisan masyarakat. Pasal 34 Ayat (2) UUD RI Tahun 1945 memberi amanat agar negara mengembangkan sistem jaminan sosial bagi seluruh rakyat dan memberdayakan masyarakat yang lemah dan tidak mampu sesuai dengan martabat kemanusiaan. Bentuk yang digunakan untuk memberdayakan masyarakat yang lemah dan tidak mampu yang sesuai dengan prinsip demokrasi ekonomi adalah koperasi. Dengan demikian, pengembangan koperasi harus diarahkan untuk menciptakan keseimbangan dan keadilan di segala bidang kehidupan dan penghidupan rakyat. Tujuan utama koperasi adalah untuk memenuhi kebutuhan hidup anggotanya dengan jalan menyelenggarakan aktivitas ekonomi secara bersama-sama. Kolektivitas adalah kekuatan koperasi, di mana maju mundurnya sebuah koperasi ditentukan oleh kemampuan para anggotanya mempertahankan kolektivitas itu. Kolektivitas (jamaah) adalah anjuran syariah. Betapa pentingnya kolektivitas itu sehingga dalam ibadah ritual pun seperti salat lima waktu, umat Muslim diperintahkan untuk mengerjakannya secara bersama-sama. Kolektivitas adalah modal sosial yang amat diperlukan untuk mencapai kemajuan. Betapapun umumnya perekonomian rakyat berukuran dan bermodal kecil, jika mereka bersatu maka mereka akan kuat. ${ }^{1}$ Dalam koperasi, setiap orang memeroleh hasil ekonomi sesuai dengan usahanya. Semakin sering anggota memanfaatkan jasa koperasinya, artinya semakin rajin ia bekerja, maka semakin besar hasil ekonomi yang diperolehnya. Anggota yang pasif tidak akan mendapat apa-apa. Prinsip ini bertolak belakang dengan prinsip kapitalis yang berbasis pada kumpulan modal. Sistem ekonomi Kapitalis adalah kegiatan ekonomi hanya dinikmati oleh segelintir orang yang memiliki kekuatan modal saja,baik dari segi sumber daya maupun materi lainnya,jadi semua diukur dengan kekuatan materi,sehingga mengakibatkan terjadinya gab atau kesenjangan sosial antara golongan si kaya dan golongan miskin.Ini yang terjadi di negara Indonesia,maka dikenal dengan istilah golongan kaya makin kaya sementara golongan miskin makin

1 Gunadi T. (1955). Ekonomi dan Sistem Ekonomi Menurut Pancasila dan UUD 45, Buku I Dasar-Dasar Falsafah dan Hukum. Edisi Revisi. Bandung: Penerbit Angkasa. hlm. 295. 
terhimpit.Teori ekonomi kapitalis yang diprakarsai oleh negara barat khususnya Amerika Serikat ternyata tidak dapat menjawab permasalahan mendasar pada kehidupan masyarakat .Tingkat pengangguran dan krisis ekonomi global terus menghantui negara tersebut yang dapat mengakibatkan melambatnya pertumbuhan ekonomi.

Dalam syariah, manusia adalah makhluk paling mulia. Oleh karena itu, 'kerja' sebagai wujud kemanusiaan, harus lebih dihargai dibandingkan 'modal' sebagai wujud harta, sehingga terdapat penghormatan terhadap kemanusiaan. Koperasi berdasarkan prinsip syariah saat ini mulai dikenal dan dilaksanakan di Indonesia. Menurut data Kementerian Koperasi dan UKM, jumlah koperasi syariah kurang lebihnya 2.700-an di seluruh Indonesia. Di Kota Depok koperasi syariah sudah beroperasi dan mulai berkembang. Jumlah koperasi syariah di Kota Depok lebih dari 100 unit. Di masa mendatang, koperasi syariah akan menjadi salah satu tulang punggung perekonomian di Indonesia, mengingat mayoritas penduduk Indonesia adalah muslim. Dasar hukum beroperasinya koperasi di Indonesia adalah UU No. 25 Tahun 1992 tentang Perkopersian. Namun UU tersebut tidak mengatur tentang koperasi syariah. Hal ini berbeda dengan perbankan syariah yang telah diatur secara khusus dalam UU No.21 Tahun 2008 tentang Perbankan Syariah. Beberapa hal yang menyangkut koperasi syariah telah diatur dalam beberapa Keputusan Menteri Koperasi dan Usaha Kecil dan Menengah. Namun, pengaturan ini masih bersifat sementara dan belum memadai. Oleh karena itu, perlu kajian berbagai aspek hukum tentang koperasi syariah. Untuk itu dilakukan penelitian dengan identifikasi masalah: "Bagaimana kesesuaian prinsip koperasi dengan prinsip ekonomi syariah? Landasan hukum apa yang digunakan dalam operasional Koperasi syariah saat Ini?, Bagaimana Eksistensi koperasi syariah di Kota Depok? Penelitian ini bertujuan untuk mengetahui kesesuaian prinsip koperasi dengan prinsip ekonomi syariah, landasan hukum yang digunakan dalam operasional koperasi syariah saat ini, dan eksistensi koperasi syariah di Kota Depok. Penelitian dilakukan dengan menggunakan pendekatan yuridis normatif. Penetapan sampel ditentukan secara purposive sampling. Teknik pengumpulan data dilakukan dengan studi dokumen dan studi kepustakaan (Library Research). Analisis data dilakukan dengan analisis kualitatif, yaitu menguraikan data dalam bentuk kalimat sesuai dengan bahasan. Analisis dilakukan melalui interpretasi baik melalui 
interpretasi gramatikal, interpretasi historis, dan interpretasi komparatif.

\section{B. PEMBAHASAN}

Kesesuaian Prinsip Koperasi Dengan Prinsip Ekonomi Syariah Ada tiga pendapat yang berkembang di masyarakat mengenai eksistensi unit usaha koperasi dalam sistem ekonomi Indonesia. Pendapat pertama mengutarakan perlunya kajian ulang apakah unit usaha koperasi masih perlu dipertahankan keberadaannya dalam kegiatan ekonomi. Secara implisit, pendapat ini menghendaki agar tidak perlu mempertahankan eksistensi koperasi sebagai unit usaha ekonomi. Pendapat ini mewakili pemikiran kanan baru yang tidak begitu mempermasalahkan konsentrasi kekuasaan ekonomi di kalangan segelintir orang dalam masyarakat dan tidak menghendaki adanya pertanda pandangan populis di dalam masyarakat. Pendapat yang kedua, memandang bahwa unit usaha koperasi perlu dipertahankan seadanya saja. Dalam alur pemikiran ini, unit usaha koperasi dipandang perlu untuk dipertahankan sekadar untuk tidak dianggap menyeleweng dari UndangUndang Dasar 1945. Pendapat yang ketiga, selalu dilontarkan oleh kalangan intelektual yang berideologi kerakyatan. Kalangan ini memandang unit usaha koperasi sebagai organisasi ekonomi rakyat yang harus dikembangkan menjadi unit usaha yang kukuh dalam rangka proses demokratisasi ekonomi. Pendapat yang didasarkan atas citacita kemerdekaan Indonesia, seperti yang termaktub dalam Undang-Undang Dasar 1945, menganggap pengembangan koperasi sebagai unit ekonomi untuk tujuan mengubah dialektik hubungan ekonomi kolonial yang ada sejak zaman kolonial Belanda menjadi dialektik hubungan ekonomi yang akan menjadikan rakyat banyak sebagai kekuatan ekonomi di samping kekuatan ekonomi sektor Pemerintah. Proses perubahan ini mengandung pengertian mengenai perlunya restrukturisasi ekonomi untuk mewujudkan keseimbangan dalam penguasaan sumbersumber ekonomi. ${ }^{2}$ Terlepas dari tiga pendapat di atas, koperasi merupakan lembaga ekonomi yang diamanatkan oleh konstitusi sebagai alat perjuangan ekonomi rakyat karena pembinaan koperasi ini sudah diatur dalam undang-undang, GBHN, APBN dan peraturanperaturan pemerintah. ${ }^{3}$ Pasal 33 ayat (1) UUD 1945 menyatakan

2 Arief S. (1988). Pembangunanisme dan Ekonomi Indonesia, Pemberdayaan Rakyat dalam Arus Globalisasi. Jakarta: Penerbit Zaman Wacana Mulia. hlm. 267.

${ }^{3}$ Harahap S.Y. (1992). Akuntansi Pengawasan dan Manajemen dalam Perspektif Islam. Jakarta: Fakultas Ekonomi Trisakti. hlm. 89. 
bahwa perekonomian disusun sebagai usaha bersama berdasarkan asas kekeluargaan. Dalam penjelasan dikemukakan bahwa dalam Pasal 33 tercantum dasar demokrasi ekonomi, produksi dikerjakan oleh semua untuk semua di bawah pimpinan atau pemilikan anggota-anggota masyarakat. Kemakmuran masyarakatlah yang diutamakan, bukan kemakmuran orang seorang. Oleh sebab itu, perekonomian disusun sebagai usaha bersama berdasarkan usaha kekeluargaan. Bangun perusahaan yang sesuai dengan itu adalah koperasi. ${ }^{4}$ Menurut Baswir, landasan dan asas koperasi umumnya terdiri atas tiga hal, sebagai berikut: ${ }^{5}$

1) Pandangan hidup dan cita-cita moral yang ingin dicapai suatu bangsa. Unsur ini lazimnya disebut sebagai landasan citacita atau landasan ideal yang menentukan arah perjalanan usaha koperasi.

2) Semua ketentuan atau tata tertib dasar yang mengatur agar falsafah bangsa, sebagai jiwa dan cita-cita moral bangsa, benar-benar dihayati dan diamalkan. Unsur landasan koperasi

4 Arief S. (1988). Pembangunanisme dan Ekonomi Indonesia, Pemberdayaan Rakyat dalam Arus Globalisasi. Jakarta: Penerbit Zaman Wacana Mulia. hlm. 267.

${ }^{5}$ Baswir R. (2000). Koprasi Indonesia (Edisi Pertama). Yogyakarta: BPFE. hlm. 35. yang kedua ini disebut sebagai landasan struktural.

3) Adanya rasa dan karsa untuk hidup dengan mengutamakan tindakan saling tolong-menolong di antara sesama manusia berdasarkan ketinggian budi dan harga diri, serta dengan kesadaran sebagai makhluk pribadi yang harus bergaul dan bekerja sama dengan orang lain. Sikap dasar yang demikian ini dikenal sebagai asas koperasi. Landasan dan asas sebagaimana di atas adalah landasan dan asas koperasi yang berlaku secara universal. Landasan dan asas koperasi seperti itu terdapat di dalam lingkungan bangsa manapun. Tanpa ketiga unsur tersebut sebagai landasan dan asasnya, koperasi tidak mungkin dapat berdiri dengan kokoh. Pasal 2 UU No. 25/1992 menetapkan kekeluargaan sebagai asas koperasi.7 Hal ini sejalan dengan penegasan ayat 1 Pasal 33 UUD 1945 beserta penjelasannya. Semangat kekeluargaan ini merupakan pembeda utama antara koperasi dengan bentuk-bentuk perusahaan lainnya. Prinsip-prinsip koperasi di Indonesia terdapat dalam Pasal 5 Ayat 1 Undangundang No. 25/1992, koperasi Indonesia melaksanakan prinsip-prinsip koperasi sebagai berikut. 
Pertama, keterbukaan. Bahwa siapapun dapat menjadi anggota koperasi tanpa memandang agama, etnis, afiliasi politik, dan perbedaan lainnya. Prinsip ini adalah perwujudan dari perintah syariah agar perbuatan manusia menjadi rahmat bagi seluruh alam.

Kedua, keadilan, bahwa distribusi manfaat ekonomi di kalangan anggota harus sesuai dengan kekerapan anggota menggunakan jasa koperasi, bukan berdasarkan proporsi modal anggota dalam koperasi. Dengan kata lain, dalam koperasi, setiap orang memperoleh hasil ekonomi sesuai dengan usahanya. Semakin sering anggota memanfaatkan jasa koperasinya, artinya semakin rajin ia bekerja, maka semakin besar hasil ekonomi yang diperolehnya. Anggota yang pasif tidak akan mendapat apa-apa. Prinsip ini bertolak belakang dengan prinsip kapitalis yang berbasis pada kumpulan modal.Disamping itu dengan keadilan ekonomi,setiap individu akan mendapatkan haknya sesuai dengan kontribusi masing-masing. Setiap individu pun harus terbebaskan dari eksploitasi individu lainnya.Islam dengan tegas melarang seorang muslim merugikan orang lain. ${ }^{6}$

6 Muhammad Syafii Antonio. (2001). Bank Syariah dari Teori ke Praktek. Jakarta: Gema Insani Press. hlm. 15.
Ketiga, penghormatan terhadap kemanusiaan. Prinsip ini diberlakukan dengan cara membatasi keuntungan dari saham yang ditanamkan anggota di koperasi. Dengan prinsip ini, pengaruh harta dibatasi, tetapi tidak, dengan pengaruh kerja. Anggota memperoleh manfaat dari koperasi sebanding dengan kerjanya, bukan dengan modal yang disimpannya di koperasi.

Keempat, otonomi, yaitu anggota mengendalikan sepenuhnya ke arah mana dan bagaimana usaha koperasi diselenggarakan. Otonomi adalah bentuk lain dari kemerdekaan atau kebebasan.

Kelima, kebebasan mengemukakan pendapat atau keinginan. Dalam koperasi prinsip ini disebut satu orang satu suara. Prinsip ini tidak berarti segala keputusan diambil dengan jalan voting. Justru kecenderungan dalam koperasi, prinsip satu orang satu suara ini diterapkan melalui musyawarah mufakat yang melibatkan seluruh anggotanya. Keadaan ini hanya bisa berlaku jika ada kesetaraan. Dalam koperasi tidak ada buruh dan majikan. Yang ada adalah persekutuan orang yang setara untuk menyelenggarakan aktivitas ekonomi bersama.

Keenam, pendidikan anggota, yaitu pendidikan untuk menanamkan karakter 
positif seperti sifat tekun, pantang menyerah, aktif melakukan inovasi, solider terhadap sesama, serta karakter lain yang diperlukan untuk kemajuan, bersamaan dengan pendidikan untuk mengasah wawasan dan keahlian anggota dalam mengelola koperasinya.

Ketujuh, kerja sama aktif antarsesama koperasi. Ikhtiar untuk mencapai perbaikan ekonomi pasti menghadapi banyak tantangan. Semakin berat tantangannya akan semakin sulit dihadapi sendirian. Karena itu satu koperasi harus bersatu dan mengembangkan kerja sama yang solid dengan koperasi lainnya atau bersatu dengan pengorganisasian yang baik. ${ }^{7}$ Berkaitan dengan kesesuaian prinsip koperasi dengan Ekonomi Syariah, perlu dikaji bahwa kegiatan atau kajian tentang ekonomi dalam Islam dimasukkan pada bagian muamalah. Muamalah mempunyai dua macam, yaitu muamalah yang berkaitan dengan pemenuhan kebutuhan materi (muamalah madiyah), dan muamalah yang menyangkut pergaulan hidup sosial (muamalah al-adabiyah). Secara filosofis, ekonomi syariah dilandaskan pada asas ketuhanan (tauhid), yaitu adanya hubungan dari aktivitas ekonomi, tidak saja dengan sesama manusia, tetapi juga dengan Tuhan sebagai

\footnotetext{
${ }^{7}$ Baswir R. (2000). Koprasi Indonesia. Edisi Pertama. Yogyakarta: BPFE. hlm. 50-52.
}

pencipta. Dari landasan tauhid ini timbul prinsip-prinsip dasar bangunan kerangka sosial, hukum, dan tingkah laku, yang di antaranya adalah prinsip khilafah, keadilan ('adalah), kenabian (nubuwwah), persaudaraan (ukhuwwah), kebebasan yang bertanggung jawab (Al-huriyah wal mas'uliyyah). Selain itu, ada nilai-nilai instrumental, yaitu larangan riba, zakat, kerjasama ekonomi, jaminan sosial, dan peran negara. Syariah Islam sebagai suatu syariat yang dibawa oleh Rasul terakhir memiliki sifat yang komprehensif dan universal. Komprehensif berarti merangkum seluruh aspek kehidupan manusia baik ritual (ibadah) maupun sosial (muamalah). Universal artinya dapat diterapkan dalam setiap waktu dan tempat. Islam melarang riba karena merupakan sumber bahaya dan kejahatan sosial.Bunga akan menyengsarakan dan menghancurkan masyarakat melalui pengaruhnya terhadap karakter manusia.Diantaranya,bunga menimbulkan perasaan cinta terhadap uang dan hasrat untuk mengumpulkan harta bagi kepentingannya sendiri,tanpa mengindahkan peraturan dan peringatan Alloh S.W.T. ${ }^{8}$

Dari pengertian dan prinsip-prinsip koperasi dapat disimpulkan bahwa falsafah

\footnotetext{
${ }^{8}$ Muhammad Syafii Antonio. (2001). hlm. 77.
} 
atau nilai etik yang mendasari gagasan koperasi adalah kerjasama, gotong royong, dan demokrasi ekonomi menuju kesejahteraan umum. Dengan melihat falsafah dan etik yang mendasari gerakan koperasi, maka banyak ditemukan persamaan dan diberi rujukan dari segi ajaran Islam, khususnya berkaitan bidang ekonomi syariah antara lain pada penekanan akan pentingnya kerjasama dan tolong menolong (ta'awun), persaudaraan (ukhuwah) dan pandangan hidup demokrasi (musyawarah).11 Islam sangat menganjurkan kerjasama dan tolong menolong seperti disebutkan dalam Q.S. Al-Maidah (5) Ayat 2, yang artinya "Dan tolong menolonglah kamu dalam (mengerjakan) kebajikan dan taqwa, dan jangan tolong menolong dalam berbuat dosa dan pelanggaran." Selain tolong menolong dan kerjasama koperasi ditekankan unsur musyawarah. Islam sangat menganjurkan musyawarah dalam mencapai kesatuan pendapat, dalam melakukan langkah-langkah untuk mencapai sesuatu.

Anjuran musyawarah terdapat dalam Q.S. Ali-Imran (3) Ayat 59, yang artinya "Musyawarahkan kamu sekalian dalam segala urusanmu." Kesesuaian koperasi dengan Islam selain dapat dilihat dari asas dan prinsip koperasi, dapat pula dilihat dari mekanisme operasional, yakni sistem imbalam (keuntungan atau fasilitas yang dapat diterima anggota), yaitu sesuai dengan peran serta kontribusinya bagi koperasi. Hal ini sesuai dengan prinsip balas jasa dalam Islam yang tertera dalam Q.S. Al-Zalzalah Ayat 7-8, yang artinya "Barangsiapa yang mengerjakan kebaikan seberat dzarrah pun niscaya dia akan melihat (balasannya). Dan barangsiapa yang mengerjakan kejahatan seberat dzarrah pun, niscaya dia akan melihat (balasannya) pula." B. Landasan Hukum yang Digunakan Dalam Operasional Koperasi Syariah UU No. 25/1992 tentang Pokok-Pokok Perkoperasian menetapkan landasan koperasi di Indonesia sebagai berikut:

1. Landasan Idiil Sesuai dengan Bab II No. 25/1992, landasan idiil Koperasi Indonesia adalah Pancasila. Penetapan Pancasila sebagai landasan Koperasi Indonesia ini didasarkan atas pertimbangan bahwa Pancasila adalah pandangan hidup dan ideologi bangsa Indonesia. Pancasila merupakan jiwa dan semangat bangsa Indonesia dalam kehidupan berbangsa dan bernegara, serta merupakan nilai-nilai luhur yang ingin diwujudkan oleh bangsa Indonesia dalam kehidupan sehari-hari. Dengan kedudukan seperti itu maka Pancasila diterima sebagai landasan idiil koperasi ataupun organisasi-organisasi lainnya di Indonesia. Pancasila, dengan 
masing-masing silanya, menjadi pedoman yang akan mengarahkan semua tindakan koperasi dan organisasi-organisasi lainnya itu dalam mengemban fungsinya masingmasing di tengah-tengah kehidupan masyarakat.

\section{Landasan Struktural Selain} menempatkan Pancasila sebagai landasan idiil koperasi Indonesia, Bab II UU No. 25 Tahun 1992 menempatkan UUD 1945 sebagai landasan strukturil Koperasi Indonesia. Sebagaimana diketahui, UUD 1945, merupakan aturan pokok ketatanegaraan Negara Republik Indonesia yang berdasarkan Pancasila. Dalam Undangundang Dasar 1945 terdapat berbagai ketentuan yang mengatur berbagai aspek kehidupan Bangsa Indonesia dalam bernegara. Dalam UUD 1945 diatur mekanisme hubungan antar lembagalembaga negara, kedudukan, tugas, dan wewenang masing-masing lembaga negara, serta ketentuan-ketentuan lain yang dipandang perlu keberadaannya sebagai pedoman dasar penyelenggaraan Negara Republik Indonesia. ${ }^{9}$ Untuk merealisasikan ketentuan Pasal 33 ayat (1) UUD 1945, pembentuk UndangUndang telah mengundangkan UndangUndang No. 12 Tahun 1967 tentang Pokokpokok Perkoperasian. Setelah undangundang ini

\footnotetext{
${ }^{9}$ Baswir R. (2000). hlm. 30-38.
}

berlaku selama 25 tahun barulah diadakan penyempurnaan dengan diundangkannya Undang-Undang No. 25 Tahun 1992 tentang Perkoperasian. Landasan hukum koperasi syariah, landasan idiil dan landasan struktural tidak berbeda dengan koperasi pada umumnya, namun berkaitan dengan landasan operasional UU No. 25 tahun 1992 tentang perkoperasian tidak sepenuhnya dapat digunakan. Karena UU Perkoperasain tidak mengatur tentang koperasi syariah, beroperasinya koperasi syariah merujuk pada:

(1) Surat Menteri Dalam Negeri RI cq. Direktorat Jenderal Pembangunan Daerah (BANGDA), tanggal 14 April 1997 Nomor 538/PKK/IV/1997 Tentang Status Badan Hukum untuk Lembaga Keuangan Syariah; (2) Surat dari Menteri Dalam Negeri RI cq. Direktorat Jenderal Pembangunan Daerah (BANGDA), tanggal 2 Agustus 1997 Nomor 193/2129/Bangda;

(3) Peraturan Pemerintah Nomor 9 Tahun 1995 Tentang Pelaksanaan Kegiatan Usaha Simpan Pinjam Oleh Koperasi;

(4) Romawi II angka I Keputusan Menteri Koperasi, Pengusaha Kecil Dan Menengah Republik Indonesia Nomor: 351/Kep/M/XII/1998 Tentang Petunjuk Pelaksanaan Kegiatan Usaha Simpan Pinjam Oleh Koperasi. Mengingat perkembangan koperasi syariah yang begitu cepat, pada tahun 2004 dikeluarkan 
Keputusan Menteri Negara Koperasi dan Usaha Kecil dan Menengah No. 91/Kep/M.KUKM/IX/2004 tentang

Petunjuk Pelaksanaan Kegiatan Usaha Koperasi Jasa Keuangan Syariah. Sesuai dengan namanya, Keputusan Menteri ini bertujuan mengatur kegiatan koperasi jasa keuangan yang beroperasi dengan menggunakan prinsip syariah. Beberapa hal yang diatur dalam keputusan ini adalah:

1) Pengertian Koperasi Jasa Keuangan Syariah Menurut keputusan ini Koperasi Jasa Keuangan Syariah adalah Koperasi yang kegiatan usahanya bergerak di bidang pembiayaan, investasi, dan simpanan sesuai dengan pola bagi hasil ( syariah). Unit Jasa Keuangan Syariah (UJKS+adalah unit koperasi yang bergerak di bidang usaha pembiayaan, investasi, dan simpanan sesuai dengan pola bagi hasil (syariah) sebagai bagian dari koperasi yang bersangkutan.

2) Tujuan pengembangan KJKS menurut Pasal 2 Keputusan ini adalah: (1) meningkatkan program pemberdayaan ekonomi, khususnya di kalangan usaha mikro, kecil,menengah dan koperasi melalui sistem syariah. (2) mendorong kehidupan ekonomi syariah dalam kegiatan usaha mikro, kecil, dan menengah khususnya dan ekonomi Indonesia pada umumnya. (3) meningkatkan semangat dan peran serta anggota masyarakat dalam kegiatan KJKS. Keputusan Menteri Koperasi dan UKM tersebut, antara lain, mengatur: Tentang Uraian Persyaratan dan Tatacara Pendirian (Bab III Pasal 3 s.d. Pasal 9). Persyaratan dan Tatacara Pendirian KJKS dan UJKS pada dasarnya hampir sama dengan Persyaratan dan Tatacara Pendirian Koperasi pada umumnya, yakni mengacu ke PP No. 4 tahun 1994 tentang Persyaratan dan Tatacara Pengesahan Akta Pendirian dan Perubahan Anggaran Dasar Koperasi serta Keputusan Menteri Negara Koperasi dan UKM No. 104.1/Kep/M.KUKM/X/2002 tentang Petunjuk Pelaksanaan Pembentukan, Pengesahan Akta Akta Pendirian dan Perubahan Anggaran Dasar Koperasi Persyaratan Pembukaan Jaringan Kantor (Bab IV, Pasal 10-Pasal 12) Pembukaan jaringan kantor dapat dilakukan paling cepat 2 tahun sejak KJKS berbadan hukum. Permohonan persetujuan diajukan kepada pejabat koperasi di tempat kedudukan koperasi tersebut ditembuskan ke pejabat koperasi dimana terletak kantor cabang. Pengelolaan (Bab V Pasal 14 s.d. Pasal 18) Bagian ini menetapkan tentang Dewan Pengawas syariah sebagai organ koperasi dan persyaratan pengelola KJKS, antara lain harus mempunyai keahlian di bidang keuangan atau pernah mengikuti pelatihan keuangan syariah atau pernah magang di Lembaga Keuangan Syariah. 
Produk dan layanan (Bab VIII Pasal 22 s.d.) Layanan yang dapat diberikan oleh KJKS adalah penghimpunan dana dalam bentuk tabungan dan simpanan berjangka, serta pembiayaan. Selain itu KJKS dapat menjalankan kegiatan pengumpulan dan penyaluran dana Zakat, Infak, Shadaqah, termasuk wakaf. Kegiatan penghimpunan dan penyaluran dana ini harus mengacu pada Fatwa Dewan Syariah Nasional MUI. Pembinaan (Bab XI Pasal 30 s.d. Pasal 32) Pembinaan terhadap KJKS dilakukan oleh Pemerintah dan Dewan Pengawas Syariah. Dewan Pengawas Syariah bertugas melakukan pengawasan pelaksanaan kegiatan usaha KJKS/UJKS berdasarkan prinsip-prinsip syariah dan melaporkan hasil pengawasannya kepada pejabat. Sanksi (Bab XIII Pasal 38 s.d. Pasal) Berkaitan dengan sanksi hanya mengatur sanksi diberikan kepada KJKS yang tidak memberikan laporan keuangan, tidak ada sanksi bagi KJKS yang dalam melaksanakan kegiatannya tidak menggunakan prinsip syariah tetapi menggunakan bunga. Peraturan Menteri tersebut merupakan peraturan sementara karena tidak memiliki kekuatan hukum sebagaimana halnya undang-undang.

Untuk itu dalam amandemen Undangundang Koperasi perlu diatur antara lain tentang: (1) Penegasan bahwa koperasi dapat melakukan kegiatan usaha baik konvensional maupun dengan menggunakan prinsip syariah. (2) Batasan Prinsip syariah, apa yang dimaksud dengan prinsip syariah dalam undang-undang ini. (3) Dewan Pengawas Syariah sebagai salah satu perangkat koperasi yang berfungsi untuk mengawasi apakah dalam operasionalnya koperasi telah melaksanakan kegiatan sesuai dengan prinsip syariah. (4) Penegasan bahwa koperasi syariah harus melaksanakan kegiatan dengan menggunakan prinsip syariah. (5) Jenis-jenis usaha berdasarkan prinsip syariah yang dapat dilakukan oleh koperasi syariah. (6) Kriteria bagi pendiri atau pengurus koperasi syariah. (7) Pengaturan tentang kebolehan koperasi syariah menghimpun dana dalam bentuk wakaf, zakat,infaq shadaqah sesuai dengan Undang-undang wakaf dan UndangUndang Zakat. (8) Penegasan Departemen Koperasi sebagai pembina dan pengawas koperasi syariah. (9) Sanksi bagi koperasi syariah yang tidak melaksanakan kegiatan sesuai dengan prinsip syariah.

Saat ini RUU hasil inisiatif pemerintah untuk mengamandemen UU Koperasi telah masuk dalam agenda Badan Legislatif nasional (Balegnas) untuk masuk ke dlam program legislatif nsional (prolegnas). C. Eksistensi Koperasi Syariah di Kota Depok 
Seperti telah diuraikan, Koperasi di Kota Depok pada tahun 2009 berjumlah lebih dari 100 unit. Koperasi syariah ini ada yang dibina oleh MUI ada yang dibina oleh DMI, ada pula yang tidak dibina oleh MUI dan DMI. Saat ini di Kota Depok terdapat 3 tipe koperasi syariah, yaitu: (1) Koperasi Syariah yang memiliki Anggaran Dasar konvensional, tetapi beroperasi berdasarkan prinsip syariah. (2) Koperasi Syariah yang memiliki Anggaran Dasar konvensional, dan beroperasi menggunakan sistem konvensional (bunga). (3) Koperasi Syariah yang memiliki Anggaran Dasar berdasarkan prinsip syariah dan beroperasi berdasarkan prinsip syariah. Berkenaan dengan peran dan fungsi Dewan Pengawas Syariah dalam struktur organisasi koperasi, Dewan Pengawas Syariah memiliki peran yang sangat besar yaitu untuk menjaga kepatuhan koperasi terhadap prinsip Islam. Selain itu juga untuk menerjemahkan fatwa Dewan Syariah Nasional (DSN) sebelum diterapkan pada koperasi syariah. ${ }^{10}$ Dilihat dari status badan hukumnya ada dua, yaitu: (1) $80 \%$ koperasi syariah di Kota Depok belum memiliki status badan hukum koperasi. Hal ini dikarenakan Anggran Dasar koperasi tersebut belum disahkan oleh Menteri Koperasi dan UKM.

10 Mubarok J. (2004). Perkembangan Fatwa Ekonomi Syariah di Indonesia. Jakarta: Pustaka Bani Quraisy. hlm. 11.
Pengesahan Anggaran Dasar Koperasi oleh Menteri Koperasi dan UKM ini dalam pelaksanaannya dilimpahkan kepada Dinas Koperasi dan UKM Kota.Umumnya para pendiri hanya memiliki Anggaran Dasar Pendirian koperasi yang dibuat oleh dan dihadapan Notaris. (2) $20 \%$ koperasi syariah telah berstatus badan hukum karena Anggran Dasar koperasi tersebut telah disahkan oleh Menteri Koperasi dan UKM. Koperasi syariah yang belum memiliki status badan hukum disebabkan dua hal, yaitu ketidakpahaman tentang konsekuensi status badan hukum dan bukan badan hukum, serta kendala finansial, baik pada proses penyusunan Anggaran Dasar oleh notaries, maupun dalam proses pengajuan pengesahan Menteri Koperasi dan UKM melalui Dinas Koperasi Kota, keberatan secara financial juga dirasakan oleh koperasi yang sudah berbadan hukum, karena dikenakan pajak yang diperlakukan sama dengan pajak untuk BUMN dan Perseroan Terbatas.

\section{PENUTUP}

Pertama, falsafah dan etik yang mendasari gerakan koperasi banyak ditemukan kesesuaian dan diberi rujukan dari segi ajaran Islam, khususnya berkaitan bidang ekonomi syariah, antara lain, pada penekanan akan pentingnya kerjasama dan tolong menolong (ta'awun), persaudaraan 
(ukhuwah), dan pandangan hidup demokrasi (musyawarah). Selain dari falsafah dan nilai etik, juga dilihat dari mekanisme operasional, yakni sistem imbalam (keuntungan atau fasilitas yang dapat diterima anggota), yaitu sesuai dengan peran serta kontribusinya bagi koperasi.

Kedua, landasan hukum koperasi syariah di Indonesia adalah landasan Idiil Pancasila, landasan Struktural UUD 1945 dan landasan operasional Surat Keputusan Menteri Koperasi dan UKM. Surat Keputusan Menteri Koperasi dan UKM ini belum memadai dan bersifat sementara sebelum amandemen UU Koperasi yang mengakomodasi koperasi syariah. Ketiga, eksistensi koperasi syariah di Kota Depok dilihat dari status badan hukumnya mayoritas belum berbadan hukum koperasi, karena Anggaran dasarnya belum disahkan oleh Menteri Koperasi dan UKM. Dilihat dari Kepemilikan Anggaran Dasar dan operasionalnya, terdapat tiga tipe koperasi syariah, yaitu: (a) Koperasi Syariah yang memiliki Anggaran Dasar konvensional, tetapi beroperasi berdasarkan prinsip syariah; (b) Koperasi Syariah yang memiliki Anggaran Dasar konvensional, dan beroperasi menggunakan sistem konvensional (bunga); (c) Koperasi Syariah yang memiliki Anggaran Dasar berdasarkan prinsip syariah, dan beroperasi berdasarkan prinsip syariah.

\section{DAFTAR PUSTAKA}

Antonio, M.Syafi'i. (2001). Bank Syariah dari Teori ke Praktek. Gema Insani Press.

Antonio, M. Syafi'i (t.t). Potensi dan Peranan Ekonomi Islam dalam Upaya Pembangunan Umat Islam Nasional.

Arief, S. (1998). Pembangunanisme dan Ekonomi Indonesia, Pemberdayaan Rakyat dalam Arus Globalisasi. Jakarta: Penerbit Zaman Wacana Mulia.

Baswir, R. (2000). Koperasi Indonesia (Edisi Pertama). Yogyakarta: BPFE.

Gunadi, T. (1995). Ekonomi dan Sistem Ekonomi Menurut Pancasila dan UUD 45. Buku I

Dasar-Dasar Falsafah dan Hukum. Edisi Revisi. Bandung: Penerbit Angkasa.

Harahap, S.Y. (1992). Akuntansi Pengawasan dan Manajemen dalam Perspektif Islam. Jakarta: Fakultas Ekonomi Trisakti.

Mubarok, J. (2004). Perkembangan Fatwa Ekonomi Syariah di Indonesia. Jakarta: Pustaka Bani Quraisy. 